\title{
米国西岸港湾の混乱による国際海上 コンテナ輸送への影響に関する基礎的研究
}

\author{
赤倉 康寛 1 ・小野 憲司2 \\ 1正会員＼cjkstart国土交通省国土技術政策総合研究所港湾研究部（†239-0826 横須賀市長瀬 3-1-1） \\ E-mail: akakura-y83ab@mlit.go.jp \\ 2 正会員 京都大学教授 防災研究所港湾物流 BCP 研究分野（土611-0011 宇治市五ヶ庄） \\ E-mail: ono.kenji.5z@kyoto-u.ac.jp
}

\begin{abstract}
高度に発展したグローバル・サプライチェーンによって，一地域で発生した災害が，世界中の経済に影 響を及ぼすようになった。このため，平常時の効率性を損なうことなく，災害の経済被害の波及をできる 限り押さえることが可能な物流網の構築が急務である.

本稿は，2014～2015 年の米国西岸港湾の混乱が，国際海上コンテナ輸送，特に，日・米間輸送に与えた 影響について，基礎的な分析を行ったものである。その結果，米国西岸港湾での荷役効率の低下状況を推 定し，日・米間の輸送日数の増加及び航空輸送・東岸港湾利用へのシフト状況から直接被害額を試算した.
\end{abstract}

Key Words : supply chain, container, US west coast port, port strike, economic impact of disaster

\section{1. 序論}

東日本大震災における，日本からの自動車部品の供給 停止を起因とした全世界の自動車生産の停帯1)は，高度 に発展したグローバル・サプライチェーンの脆弱性を明 らかにした。すなおち，一地域で発生した災害が，国際 物流を媒介に，世界中の経済に影響を及ぼすようになっ た. そのため，平常時の効率性を損なうことなく，大規 模災害による経済被害の波及をできる限り抑えることが 可能な物流網が強く求められている. 以上の背景の下, 本稿は，人為災害である2014～2015年の米国西岸港湾の 混乱が，国際海上コンテナ輸送，特に日・米間に与えた 影響について，基礎的な分析を行い，直接被害額を試算 したものである．本研究では，本稿の成果を基に，国際 物流を介して波及する経済被害の定量化手法を開発し, さらには，その有効な対策の立案を目指している.

米国西岸港湾については，2002年ロックアウトの米国 経済への被害額 : 19億ドル／日との試算（Martine Associates. $\left.{ }^{2)}\right)$ が有名であるが， Hall ${ }^{3)}$ は過大評価であると指摘 し，連邦予算議会事務局 (Congressional Budget Office） ${ }^{4)}$ は幅を持って示している．2014年には，再度の混乱発生 を危惧し，Werling5)が20日間の港湾機能停止の経済損失 額を499億ドル, Martine Associates.6)も20日間で409億ドル との推計を発表している。同様に，船瀬ら7゙は名古屋港 が半年機能停止した場合の日本経済への被害額を， IRGC ${ }^{8)}$ はマラッカ海峡が通航不可となった場合の周辺国
の経済被害をそれぞれ推計している.しかし，これらの 分析は，いずれも港湾・航路機能が完全に停止した場合 であるが，2014～2015年の西岸港湾の混乱では，港湾機 能は長い期間にわたり大きく低下したものの，停止には 至っていない.このような状況下での，荷主の経路選択 の変化や経済損失額を推計していくためには，まずもつ て実態の把握が重要である．以降，本稿では，2.にて米 国西岸港湾の混乱状況，3.にて国際海上コンテナ輸送へ の影響について述べ，4.にてとりまとめる.

\section{2. 米国西岸港湾の混乱状況}

\section{(1) 労使交渉の経緯}

米国西岸港湾では，労働者組合 ILWU（International Longshore and Warehouse Union）と船社・オペレーター団 体 PMA（Pacific Maritime Association）の労使協約の改定 交渉が 6 年毎に実施されている. 前述の通り, 2002 年の 改定では 11 日間のロックアウトが行われ, 大統領による 介入に至っている. 2014 年の労使交渉の経緯を, 表-1に 示す. 6 月に協約が失効し, PMA の発表では 10 月下旬 頃から ILWU がスローダウンを開始し，年末には荷役作 業員の不足により PMA が夜間荷役を中止した. これら の荷役停帯によりコンテナ船の沖待ちが長期化し，2 月 には PMA による譲歩案の提案・公表，休祝日荷役の中 止に至った．最終的には，オバマ大統領に派遣されたぺ 
表-1 2014 年労使交渉の経緯

\begin{tabular}{|l|l|}
\hline \multicolumn{1}{|c|}{ 時期 } & \multicolumn{2}{|c|}{ 出来事 } \\
\hline 2014年 \\
\hline 5月中旬 & 労使交渉開始 \\
\hline 6月末 & 2008年締結の労使協約失効 \\
\hline 10月下旬 & ILWUがスローダウン開始(PMA発表) \\
\hline 12月末〜 & PMAが夜間荷役を中止 \\
\hline 2015年 & \\
\hline 2月4日 & PMAがILWUに譲歩案を提案し, 公表 \\
\hline 2月11日 & PMAが休祝日の荷役中止を発表 \\
\hline 2月17日 & ペレス労働長官の仲介開始 \\
\hline 2月20日 & 暫定合意 \\
\hline
\end{tabular}

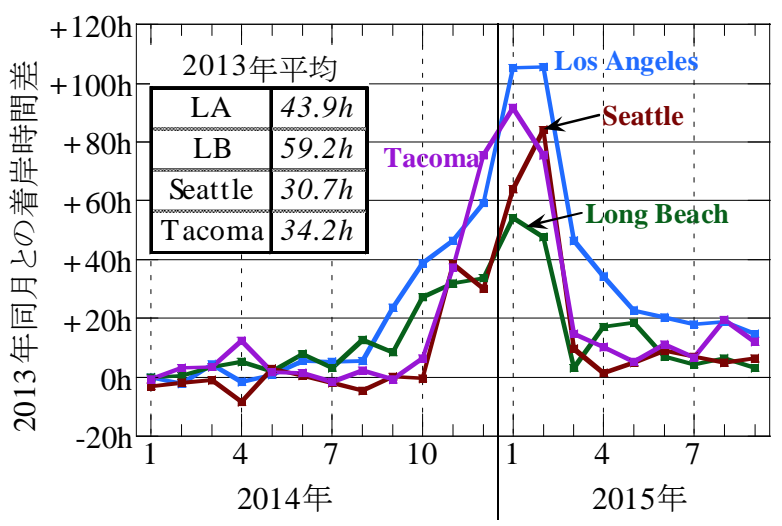

図-1 1 隻当たりのターミナル着岸時間の推移

レス労働長官の仲介により, 暫定合意にこぎ着けている.

\section{（2）ターミナル着岸時間の長期化}

ターミナルへの平均着岸時間 (1 隻当たり)の変化を,

LLI（Lloyd’s List Intelligence）の船舶動静データにより整 理した結果が，図-1 である. PSW（Pacific Southwest）の 代表港として Los Angeles と Long Beach, PNW (Pacific Northwest）の代表港として Seattle 及びTacoma を分析し た（以下，本稿での分析対象港は同じ). LLI 動静データ は各港のターミナル着岸・離岸日時の記録であり，着岸 〜離岸の時間は，ほぼ荷役時間に等しいと想定される.

図より，各港の寄港コンテナ船の 2013 年通年平均の ターミナル着岸時間が 30〜60 時間であったのに対し, PSW の 2 港は 10 月, PNW の 2 港は 11 月に急増し，い ずれもピークは1〜2月で，例えばLos Angeles では平常 時の 3 倍以上にまで達していた。 なお，荷役時間の長期 化には船舶の大型化の要素も含まれている可能性があり, 例えば Los Angeles 港では寄港コンテナ船の平均船型が 2013 年 : 4,987TEU から 2015 年 : 6,176TEU になってい る. (5)荷役効率にて，この点を踏まえた分析を行う。

\section{(3) 取扱量の推移}

各港でのコンテナ取扱量 (空込み) について，2013年 同月比を整理した結果が，図-2 である。出典は各港の Web Page であるが, Seattle と Tacoma は 2015 年 10 月に NSA（Northwest Seaport Alliance）を結成し，合計取扱量

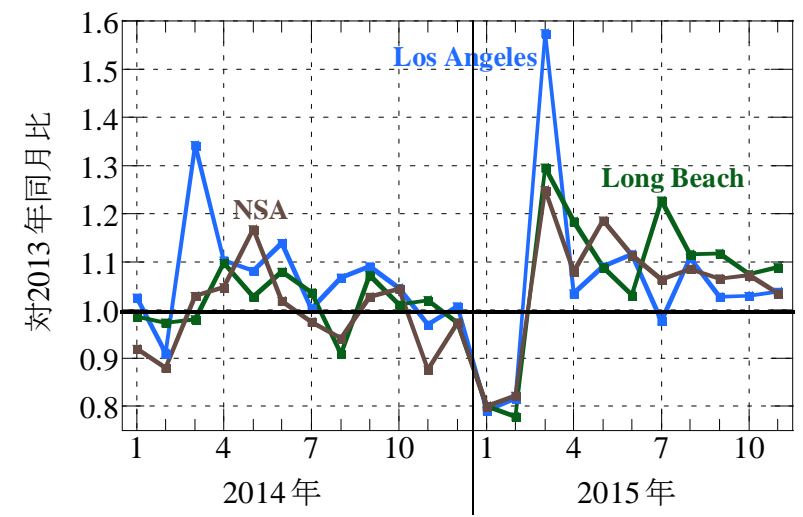

図-2 コンテナ取扱量の推移

を発表しているため NSA として整理した. 各港で変動 が見られるものの，2015 年 1～2 月は大きく減少してお り, PNWの 2 港は対 2013 年同月比約 8 割となっていた.

\section{（4）沖待ちの増加}

1 隻当たりのターミナル着岸時間が平常時の 3 倍以上 に長期化（図-1）したにもかかわらず，取扱量は約 2 割 減に収まっていた（図-2）。この差異の原因は，沖待ちの 増加と, それに起因した寄港隻数の減少にある.

沖待ちの増加状況を, AIS (船舶自動識別装置) デー タ 9)によって確認した結果が図-3 である. 海域に停泊中 のコンテナ船が，2015 年 2 月のピーク時は 30 隻超であ ったが，半年後にはほぼ解消されていた。一般に，コン テナバースの時空間での着岸船舶の占有率は 3 割前後で あり 10)，船舶が着岸していない時間帯・バースがある. しかし, 沖待ちが大量に発生している場合, 着岸コンテ ナ船が離岸した後, 直ぐに，次のコンテナ船が着岸し， インターバルがほとんどなくなる．また，沖待ちの長期 化により寄港隻数も減少し，例えば，ロサンゼルス港で は2015 年 2 月には平常時の 6 割弱であった. これらの原 因により，荷役効率が低下し，着岸時間が大幅に長期化 した中で，取扱量の減少は 2 割程度となっていた。

\section{（5） 荷役効率の分析}

各船のターミナル着岸時間が荷役時間に等しいとみ なして，荷役効率の変化を追ったのが，図-4である. 荷 役効率は, コンテナ 1 個の積み卸しに要した時間であり, 図-2の各港取扱量及び図-1の着岸時間を使用し，取扱量 (TEU) から取扱個数へは米国輸出入貨物データ : PIERS (Port Import/Export Reporting Service）の数值を用いて換 算した。この荷役効率は，船舶の大型化に比例してター ミナル着岸時間が長くなった場合，一定值となる.

図では，荷役効率はPSW の 2 港では 2014 年 10 月に 大きく低下しているのに対し，NSA では 11 月の低下と なっており，図-1 の着岸時間と傾向が一致した。2015 年 1 2 月には, いずれの港湾でも荷役効率が半分以下に 


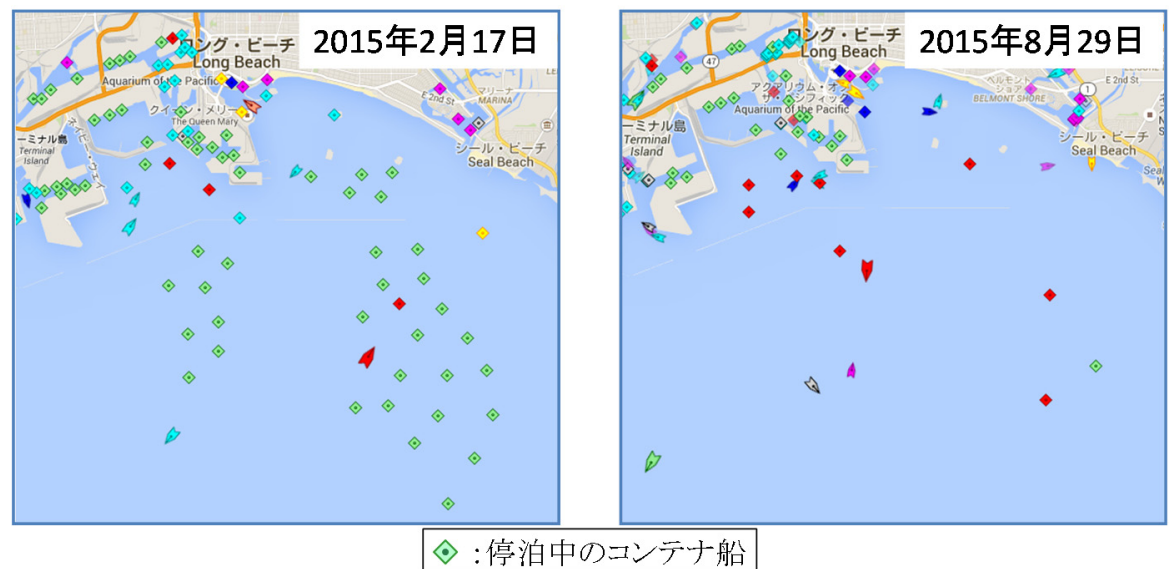

図-3 Los Angeles/Long Beach における沖待ちの状況（Marine Traffic ${ }^{9)}$ )

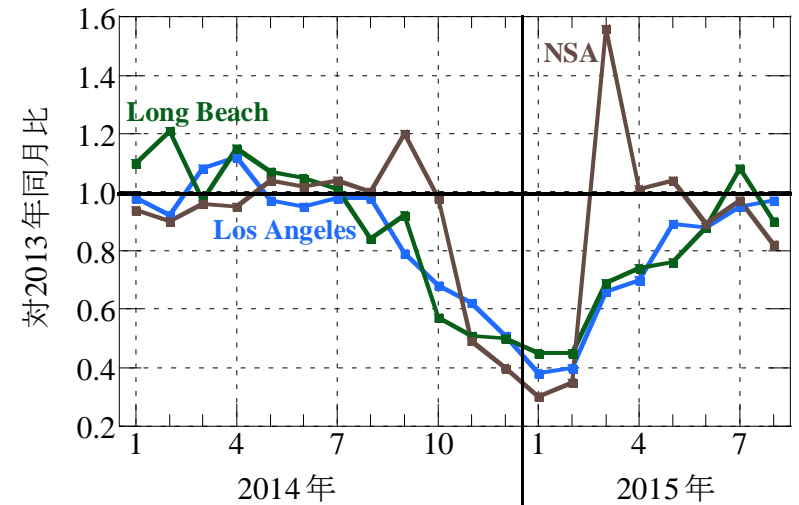

図-4 荷役効率（着岸時間／積卸個数）の推移

低下していたが，暫定合意後の 3 月では NSA が反動で 高い荷役効率を示したのに対し, PSW の 2 港では平常時 に比べ依然として低い荷役効率を示していた。

\section{3. 国際海上コンテナ輸送への影響}

\section{（1）対東アジアの西岸港湾利用率}

東アジアー米国間のコンテナ輸送では, 西岸港湾利用 （内陸部へは陸上輸送: Intermodal）と, 東岸港湾利用 (All Water）の 2 つ選択肢がある. PIERS データを用いて, 東アジア各国の西岸港湾利用率を整理したのが，図-5 で ある. どの国も2015年1〜2月に大きく低下していたが， その低下率は平常時 (2014 年前半) の西岸港湾利用率が 低いほど大きい傾向が見られた (特に韓国). 平常時に東 岸港湾を利用した経験のある荷主は, 西岸港湾混乱時に 東岸港湾経由への経路変更が容易であったことが数值に 現れたものと想定される. また，中国を除くと，平常時 の水準までは戻っていなく，一部，平常時の経路が変更 された可能性がある.

\section{(2) 対日本の輸送日数}

港湾混乱の直接的な影響として，日本一西岸港湾間の 所要日数の増加状況を算定した結果が，表-2である. 算

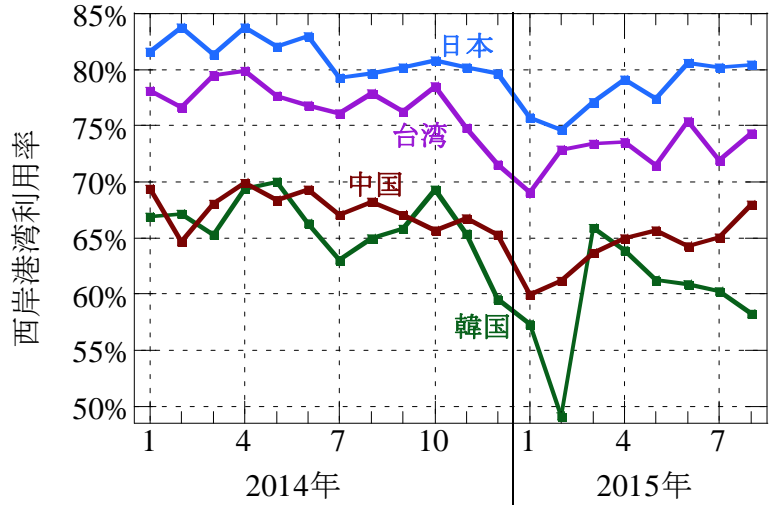

図-5＼cjkstart東アジア各国の米国西岸港湾利用率

表-2 日本一米国西岸港湾間の所用日数の変化

\begin{tabular}{|c|c|c|c|c|c|c|c|}
\hline \multirow{2}{*}{\multicolumn{2}{|c|}{}} & \multicolumn{3}{|c|}{ PNW } & \multicolumn{3}{c|}{ PSW } \\
\cline { 3 - 8 } & 全体 & 洋上 & 荷役 & 全体 & 洋上 & 荷役 \\
\hline 2014 & 東航 & 10.9 & 9.7 & 1.3 & 11.9 & 10.3 & 1.6 \\
2月 & 西航 & 14.4 & 13.2 & 1.2 & 16.5 & 15.3 & 1.2 \\
\hline 2015 & 東航 & 25.0 & 19.7 & 5.3 & 26.9 & 22.0 & 4.8 \\
2月 & 西航 & 20.9 & 15.1 & 5.8 & 20.9 & 17.4 & 3.5 \\
\hline \hline \multirow{2}{*}{ 変化 } & 東航 & +14.0 & +10.0 & +4.0 & +14.9 & +11.7 & +3.3 \\
& 西航 & +6.5 & +1.8 & +4.7 & +4.4 & +2.1 & +2.3 \\
\hline
\end{tabular}

※単位は日数. 日本側港湾は, 東京及び横浜.

定に当たっては，まず，PIERS データにより，日本一米 国西岸間の直行コンテナ輸送を担った船名を整理し,

LLI 動静データにより当該船舶の日本港湾（東京及び横 浜）と西岸港湾（PNW/PSW の計 4 港）の着岸・離岸日 時を整理した. 各所要日数 (全体: $D_{A L L}$, 洋上: $D_{S E A}$, 荷役：D $D_{T E R M} ）$ の定義は，以下のとおり.

$$
\begin{gathered}
D_{A L L}=D_{S E A}+D_{T E R M} \\
D_{S E A}= \begin{cases}d_{\text {USarri }}-d_{\text {JPsail }} & \text { (東航) } \\
d_{\text {JParri }}-d_{\text {USail }} & \text { (西航) }\end{cases} \\
D_{T E R M}=\frac{d_{\text {USail }}-d_{\text {USarri }}+d_{\text {JPsail }}-d_{\text {JParri }}}{2}
\end{gathered}
$$

ここに, $d_{U S a r r i} \cdot d_{U S s a i l}$ : 米国西岸港湾着岸・離岸日時, $d_{\text {JParri }} \cdot d_{\text {JPsail }}$ : 日本港湾着岸・離岸日時である. 寸な わち, 洋上日数は船積港離岸から船卸港着岸までの日数, 
荷役日数は，平均的な值として，米国西岸及び日本港湾 合計の着岸日数の半分とした. 全体所要日数は, 洋上日 数と荷役日数の合計である. この洋上日数には, 沖待ち に加え, 経路上の寄港（カナダ港湾や日本の仙台塩釜・ 苫小牧等）が含まれている場合があるが，対象は日本一 米国西岸港湾を直行でコンテナ輸送した船舶のみである.

表より, 平常時の 2014 年 2 月に比べて, 混乱ピーク 時の 2015 年 2 月には, 全体所要日数が東航で約 14〜15 日，西航で約 4〜7 日増加していた. 東航と西航の差は, 基本的には西岸港湾での沖待ち時間である. 寸なわち, 西岸港湾での沖待ちが, 約 8〜9 日にも及んだことを示寸.

この輸送日数の長期化を, 輸送貨物の価值の損失とし て, 損失額を推計した. 具体的には, 輸送の増加日数に, コンテナ貨物の平均時間価值と輸送量を掛け合わせた. 増加日数は 2015 年 2 月（表-2）を基本としてターミナル 着岸時間（図-1）と比例するとみなし，コンテナ貨物の 時間価值は井山らの推計值 (欧米航路の日本輸出 : 2,146 円 $/$ 時・TEU, 輸入：1,963 円/時・TEU）11)を用いた. その結果，2014 年 10 月〜2015年 6 月で, 日本輸出: 約 1 千億円, 輸入 : 約 5 百億円との損失額試算值を得た. この損失額は，一般には輸入側の国において影響が大き いが，(4)自動車部品の日本輸出では, 米国輸送先の約 8 割が日本企業と資本関係があると見られた。

\section{(3) 事例 1 : ジャガイモ}

日本輸入貨物の中で, 大きな影響が出たと報道された 品目の一つがジャガイモである. 米国西岸港湾の混乱の 影響により，ケンタッキーフライドチキンでは約 1 ケ月 間にわたり「フライドポテト」が販売中止，マクドナル ドでも約 1 ケ月間「マックフライポテト」の販売が S サ イズのみとなった。 日本マクドナルド社は, 緊急対策と して, 航空便及び東海岸港湾からの輸入を行った ${ }^{12)}$.

コンテナ貨物のジャガイモ（生鮮・冷蔵・冷凍及び処 理後冷凍, HS Code : 0701，0710.01 及び 2004.10）につ いて, 平常時 (2013 年) の米国仕出地を整理した結果が, 図-6 である.この仕出地は, PIERS データのうち, Origin_Destination State の情報に依っており，充足率が約 4 割との問題があるが, 当該貨物の発着地を把握できる. その結果は, 仕出地の 9 割超がワシントン州であり, ほ ぼ全量が西岸地域であった。 これらの米国の輸出港湾を 整理した結果が，表-3である. 仕出地が西岸地域である ことから, 輸出港湾も西岸港湾が占めていた.

また，貿易統計（財務省）及び PIERS データにより， 西岸港湾混乱前後の輸送経路の変化を追った結果が, 図 -7 である. 貿易統計により航空・海上輸送の割合を, PIERS により海上輸送における西岸・東岸の利用率を把 握した. 日本の貿易統計と PIERS は, それぞれの通関日 で記録されているため，両者の間には輸送期間に伴うタ

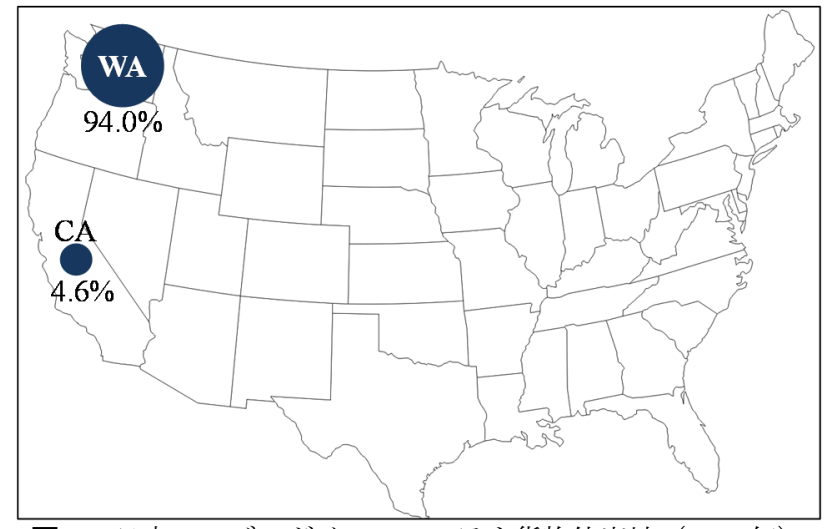

図-6日本へのジャガイモのコンテナ貨物仕出地（2013 年）

表-3 日本へのジャガイモのコンテナ貨物輸出港（2013 年）

\begin{tabular}{|c|c|r|r|}
\hline 港湾 & 地域 & $\begin{array}{c}\text { 輸出量 } \\
(' 000 \mathrm{t})\end{array}$ & 割合 \\
\hline Tacoma & 西岸 & 163.5 & $65.2 \%$ \\
Seattle & 西岸 & 71.8 & $28.6 \%$ \\
Portland (OR) & 西岸 & 7.8 & $3.1 \%$ \\
Los Angeles & 西岸 & 5.3 & $2.1 \%$ \\
Oakland & 西岸 & 2.1 & $0.8 \%$ \\
\hline
\end{tabular}

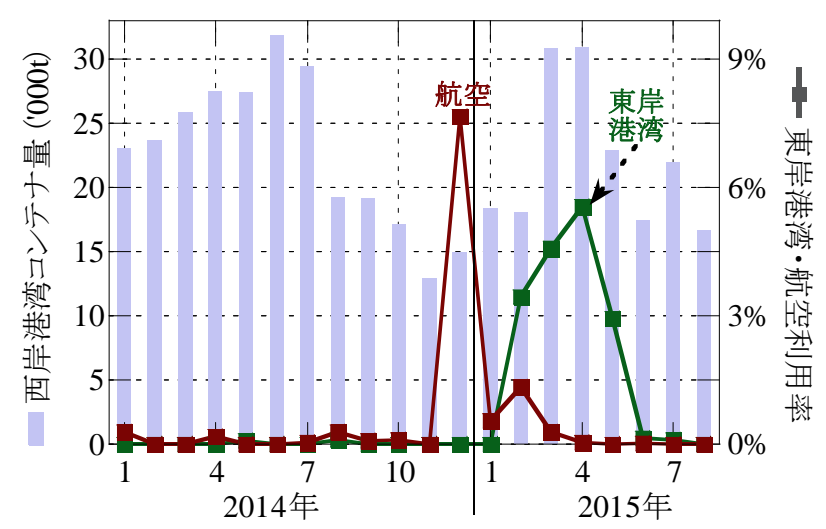

図-7 日本へのジャガイモの輸送経路の変化

イムラグある. そこで，平均的な状況として，米国西岸 港湾利用貨物は一律 15 日, 東岸港湾利用貨物は一律 30 日間を要するものとして, 日本輸入月で整理した.なお,

表-2 に示したとおり 米国西岸港湾の混乱により所要日 数が増加しているため, 西岸港湾については各月の判別 に“ずれ”が生じていると想定される.

図より, 西岸港湾コンテナ量については, 2014 年 6 月 に急増（前年比 5 割増）し，8 月から 2015 年 3 月まで大 きく減少していた，その間，不足分を補うために，2014 年 12 月には緊急対応として航空輸送がなされ, 2015 年 2 月から 5 月までは代替輸送経路として東岸港湾が利用さ れた. 2015 年 8 月には, 航空・東岸港湾ともに利用率は 0 となり, 輸送経路は平常時に戻っていた.

\section{（4）事例 2 : 自動車部品}

日本輸出貨物の中で, 影響が大きく報道されたのは自 動車部品である. 米国西岸港湾の混乱の影響により, ト 


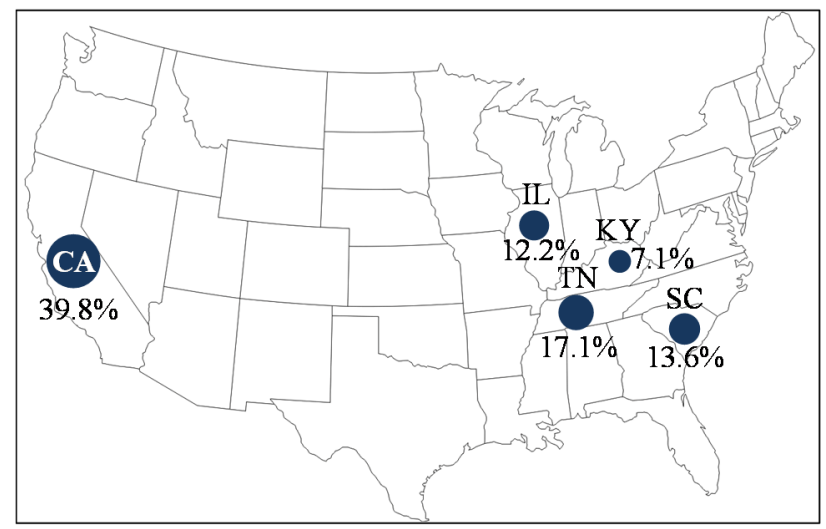

図-8 日本からの自動車部品のコンテナ貨物仕向地（2013 年）

表-4 日本からの自動車部品のコンテナ貨物輸入港（2013 年）

\begin{tabular}{|c|c|r|c|}
\hline 港湾 & 地域 & $\begin{array}{r}\text { 輸入量 } \\
\text { ('000t) }\end{array}$ & 割合 \\
\hline Los Angeles & 西岸 & 451.7 & $36.6 \%$ \\
Long Beach & 西岸 & 324.0 & $26.2 \%$ \\
Tacoma & 西岸 & 249.8 & $20.2 \%$ \\
Vancouver & カナダ & 60.5 & $4.9 \%$ \\
Seattle & 西岸 & 49.6 & $4.0 \%$ \\
Norfork & 東岸 & 36.7 & $3.0 \%$ \\
Savannah & 東岸 & 21.7 & $1.8 \%$ \\
Charleston & 東岸 & 15.7 & $1.3 \%$ \\
New York & 東岸 & 12.2 & $1.0 \%$ \\
\hline
\end{tabular}

ヨタ自動車やホンダでは，日本から米国への自動車部品 の納品が遅れ, 米国工場の減産に至っている ${ }^{13)}$.

自動車部品 (HS Code : 8708) について, 平常時 (2013 年) の米国仕向地を整理した結果が，図-8である.この 仕向地も，ジャガイモの仕出地（図-6） と同様に PIERS データの Origin_Destination State の情報に依っており, デ 一タ充足率は 5 割強である. 最大の仕向地は西岸地域の カリフォルニア州であったが，以下，テネシー州，サウ スカロライナ州，イリノイ州と東岸に近い地域が並んで いた.これらの米国輸入港湾を整理した結果が表-4であ るが，西岸港湾（カナダを含む）の割合は9割を超えて いた. 寸なわち，東岸が近い地域からも，相当程度，西 岸港湾を利用していたことが判る.

貿易統計と PIERS データを用いて, 港湾混乱前後の輸 送経路の変化を追った結果が，図-9である. データ整理 の方法は, ジャガイモの図-7 と同じであり, 日本輸出月 で整理した. 西岸港湾コンテナ量については，2015年 1 〜 月のうち 4 月を除いて 4 万 $\mathrm{t}$ を割り減少を示したも のの, 最低の 2 月においても対前年同月比は 0.75 に留ま っていた. 航空利用率は, 2014 年 6 月より増え始め, 2015 年 2 月に全体の $1 / 4$ 弱を占めたが， 2014 年 5 月以降は平 常時の水準（1\%内外）に戻っていた. 東岸港湾利用率は 平常時でも 6〜7\%見られたが, 2014 年 6 月より 1 2\%pt 高い水準で推移し，2015 年 1 月：17\%を示した． 5 月以 降も $8 \%$ を超える水準を示しており，一部，平常時の経 路が東岸港湾利用へ移った可能性が想定される.

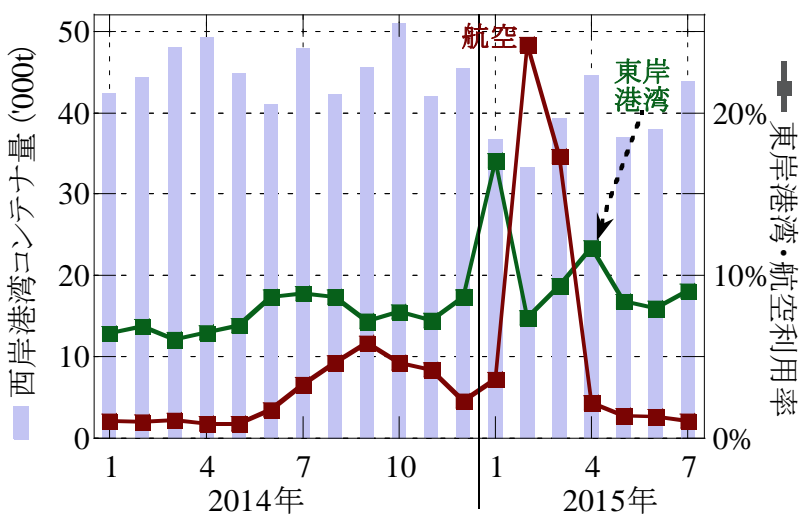

図-9 日本からの自動車部品の輸送経路の変化

ここで，富士重工業でのインディアナ州工場向け部品 のチャーター便による航空輸送の追加輸送費は 70 億円 ／月とされている ${ }^{13)}$. この情報を用いて，全航空輸送の 追加コストを試算した. 具体的には, 航空輸送の輸送単 価（t 当り）を，平常時における富士重工業の輸送量に よって算定し，2015 年 2３ 月における平常時からの航 空輸送量の増加分に掛け合わせた。 その結果は約 260 億 円と試算され，西岸港湾の混乱により，自動車部品だけ でも，多額の追加輸送コストが発生していたことが確認 された.

\section{（5） 今後の進め方}

これまでの分析結果を踏まえ，今後，米国西岸港湾混 乱に起因したコンテナ輸送の遅滞による, 日本経済全体 への被害を評価していく. 具体的には, 貨物の品種別 (HS コードを想定)に, 以下の 3 項目の直接被害を推計する.

i) 輸送遅滞の影響度 : 生鮮食品等は遅滞により商品の価 值が大きく低下寸る. その場合, 時間価值ではなく, 商品の価值が失われたとして被害額を推計する.

ii) 代替輸送量の把握 : 事例 1 及び 2 で見られたように, 東岸港湾利用及び航空輸送への経路変更が見られた。 代替輸送量を把握し，追加の輸送費を推計する.

iii) 輸送中止量の推計 : 輸送を中止した貨物量について, 平常時からの減少量をもって評価する.

また，以上の直接被害額の評価により，さらに日本経 済における間接被害額の推計や, 米国・ 韓国・中国等他 国における被害額の定量化をも目指寸。

このような経済被害の波及を抑制するための対策と しては, 荷主側と船会社・港湾側の両方での対応が考え られる. 荷主側では, 平常時より代替輸送経路を確保し ておくことである. 図-5において，平常時に東岸港湾利 用率が高かった韓国が，混乱時に代替輸送経路として東 岸港湾を高い割合で選択していたように, 複数経路の確 保は，災害時における対応能力を高めることとなる。

YKK は, 製品輸出において, 名古屋港が使用できない場 合に，全量を伏木富山港から輸出できる体制を整え，輸 
送契約にも反映させている ${ }^{14)}$ 。このような例は一つの対 応方法であるが，例 1 のジャガイモのように，米国内の 目的地が西岸地域の場合に東岸港湾経由の経路を維持す るのは，合理的ではない.

船会社・港湾側では，混乱や災害発生時に他港湾への 寄港を，より容易に選択可能とする方法が考えられる. 具体的には、港湾運送業も含む総合的な港湾同士の代替 協定や，荷主と船社の輸送契約の融通性を高める可能性 を検討したいと考えている．輸送契約については，北米 からの穀物輸送（バルク貨物）において，北米出港時に は船卸港湾を定めず，日本に近付いてからサイロの在庫 状況を踏まえて船卸港湾を決めるスワップ輸送が行われ ている. これに準じ，何らかの理由で，寄港不能，ある いは，長い期間の沖待ちが見込まれる場合に，円滑に， 予め定めた代替港湾での荷卸しを選択可能とする制度も 考えられる. 今後，このような対応策の可能性を，制度 分析や関係者へのヒアリング等により模索していく.

\section{4. 結論}

本稿では，人為災害である 2014２015 年の米国西岸 港湾の混乱が，国際海上コンテナ輸送，特に日・米間に 与えた影響について, 基礎的な分析を行った. その結果, 米国西岸港湾での荷役効率の低下状況を推定し，日・米 間の輸送日数の増加及び航空輸送・東岸港湾利用へのシ フト状況から直接被害額を試算した。今後，直接・間接 被害額の定量化や対策効果の評価を行い，よりリダンダ ンシーの高い国際物流網の構築につなげていきたい.

謝辞 : 本研究は JSPS 科研費（16K01272）の助成を受け たものです。

\section{参考文献}

1) 小野憲司, 赤倉康宽, 神田正美 : 自動車産業サプライ チェーンに対する東日本大震災のインパクト分析, 日 本物流学会誌, No.23, pp.127-134, 2015.
2) Martin Associates.: An assessment of the impact of West Coast container operations and the potential impacts of an interruption of port operations, 2001 (Commissioned by the Pacific Maritime Association).

3) Peter V. Hall: "We'd Have to Sink the Ships": Impact Studies and the 2002 West Coast Port Lockout, Economic Development Quarterly, Vol.18, No.4, pp.354-367, 2004.

4) Congressional Budget Office, The Congress of the United States: The Economic Costs of Disruptions in Container Shipments, 2006.

5) Jeffrey Werling: The National Impact of a West Coast Port Stoppage, Inforum Report, 2014 (Commissioned by the National Association of Manufacturers and the National Retail Federation).

6) Martine Associates.: Economic Impact and Competitiveness of the West Coast Ports and Factors that Could Threaten Growth, 2014 (Commissioned by the Pacific Maritime Association).

7）船瀬悠太，多々納裕一，土谷哲 : 港湾の機能停止の国 際経済への影響分析 : 空間的応用一般均衡アプローチ, 土木学会論文集 D3, Vol.67, No.5, pp.I_243-I_254, 2011.

8) International Risk Governance Council: Risk Governance of Maritime Global Critical Infrastructure: The example of the strait of Malacca and Singapore, Geneva, 2011.

9) Marine Traffic:ライブ・マップ, https://www.marinetraffic. $\mathrm{com} / \mathrm{jp} /, 2015$ 年 2 月 17 日及び 8 月 19 日アクセス.

10) 赤倉康寬, 安藤和也：AIS データを利用した世界主要 コンテナターミナルのバース・ウィンドウ作成による 稼働率分析, 土木学会論文集 B3, Vol.68, No.2, pp.I_1175-I_1180, 2012.

11) 井山繁, 渡部富博, 後藤修一 : 犠牲量モデルを用いた 国際海上コンテナ貨物流動分析モデルの構築, 土木学 会論文集 B3，Vol.68，No.2，pp.I_1181-I_1186， 2012.

12) 日本マクドナルド社: アメリカ西海岸港湾労使交渉の 長期化による「マックフライポテト」及びポテトを含 むセット商品の販売内容変更について, ニュースリリ 一ス，2014 年 12 月 15 日付, 2014.

13) 日本経済新聞社: ホンダ・トヨタ米で減産 西海岸港 湾の労使対立部品供給滞る, 2015 年 2 月 18 日付朝刊.

14）海事プレス社：YKK「BCP 海上運賃」を設定 災害 時, 伏木富山港から全量輸出, 日刊 CARGO, 2014 年 12 月 11 日付, 2014.

(2016.2.4 受付)

\section{BASIC IMPACT STUDY OF US WEST COAST DISRUPTION ON INTERNATIONAL CONTAINER TRANSPORT}

\section{Yasuhiro AKAKURA and Kenji ONO}

As a result of highly developed global supply chain, the disaster of one area will have an influence on the world economy. Therefore, to construct the resilient logistic network that can suppress the indirect economic damage of the disaster is strongly required.

This paper analyzes the influence of US west coast port disruption on international container transport. In this paper, the deterioration of efficiency of container handling at US west coast port was calculated, and the economic damage as to Japan by delaying of container transport and shifting to air transport were estimated. 